\title{
Evaluation of Sweet Basil Powder Plant (Ocimum basilicum L.) as a Feed Additives, on the Performance of broilerChicks
}

\author{
Thair Jawad Kadhim Al-Kelabi ${ }^{@}$ and Galib M. Al-Kassie \\ Department of Veterinary public health, College of Veterinary Medicine, University of Baghdad, Iraq
} dr.thear@yahoo.com

Accepted on 20/9/2012

\section{Summary}

The present study was carried out at the Poultry Farm, College of Veterinary Medicine -Baghdad University, for powder sweet basil plant evaluation as feed additives, and its effect on the performance and health of broiler. Three hundred one day old Hubbard broiler chicks were used in this study. Chicks were weighed and randomly divided into 10 treatments groups, with 2 replicates (15chicks each).These groups were fed with the following rations: The $1^{\text {st }}$ group was fed the basal diet (control group).The $2^{\text {nd }}, 3^{\text {rd }}$ and $4^{\text {th }}$ groups were fed the basal diet+0.3, 0.4 and $0.5 \%$ basil powder for the first 3 weeks only respectively. At the $5^{\text {th }}, 6^{\text {th }}$ and $7^{\text {th }}$ groups were fed the same basal diet $+0.3,0.4$ and $0.5 \%$ basil powder for the second 3 weeks respectively. While the $8^{\text {th }}, 9^{\text {th }}$ and $10^{\text {th }}$ were fed the same basal diet with $0.3,0.4$ and $0.5 \%$ basil powder along the whole six weeks. The experiment was terminated when birds were 6 weeks old. Weight gain, feed intake and feed conversion ratio were measured at the end of first three weeks and also at the end of the experiment. The results revealed that adding sweet basil powder significantly $(\mathrm{P}<0.05)$ increased live body weight, body weight gain and feed conversion ratio as compared with the control, especially on the level 3\%, 4\%, 5\% of Sweet basil powder addition along the whole period of the experiment and There was a significant $(\mathrm{P}<0.05)$ decrease in total feed intake compared with the control group.

Keywords: Sweet Basil, (Ocimumbasilicum L.), Feed Additives, broiler, Performance.

\begin{tabular}{|c|c|}
\hline Introduction & likely to become a problem than with \\
\hline $\begin{array}{l}\text { The use of herbal feed additives, which } \\
\text { include essential oils and (exotic) herbal } \\
\text { mixtures, is extensively promoted by the } \\
\text { producers, but the scientific background } \\
\text { underpinning their use often is limited. } \\
\text { Consequently an adequate knowledge of quality } \\
\text { control, content of active substance(s), stability, } \\
\text { efficacy and safety is often lacking. A critical } \\
\text { examination of bioactive plant products has to } \\
\text { cover analytical aspects, absorption, } \\
\text { bioavailability and molecular functionality in } \\
\text { addition to feeding experiments and technology } \\
\text { development. (1) } \\
\text { Herbs and herbal products/botanicals } \\
\text { represent a large array of nutraceuticals, which } \\
\text { are defined as "any non-toxic feed component }\end{array}$ & $\begin{array}{l}\text { conventional synthetic compounds ( } 2 \text { ). } \\
\text { Ocimumbasilicum has over } 50 \text { medicinal } \\
\text { activities and is reportedly used to treat over a } \\
\text { hundred conditions. Hence, } O \text {. basilicum } \\
\text { considered as antibacterial, antiseptic, a } \\
\text { febrifuge and a nervine ( } 3 \text { ). } \\
\text { Several investigators reported that using } \\
\text { medicinal and aromatic plants (MAP) in broiler } \\
\text { diets improved body weight, body weight gain, } \\
\text { feed conversion efficiency and reduce the cost } \\
\text { of feed ( } 4,5,6 \text { and } 7 \text { ). So the objective of the } \\
\text { present study is to investigate the impacts of } \\
\text { sweet basil as natural feed additives on the } \\
\text { performance of broiler chicks. }\end{array}$ \\
\hline $\begin{array}{l}\text { that has scientifically proven health benefits } \\
\text { including disease prevention or treatment such } \\
\text { as (dietary fiber, phenolic acids, flavonoids, } \\
\text { vitamins, antimicrobial agents and } \\
\text { neuropharmacological agents). One perceived } \\
\text { advantage is that many of these plant products } \\
\text { occur in complex mixtures and not only as } \\
\text { single compounds, hence resistance is less }\end{array}$ & $\begin{array}{l}\text { This experiment was carried out in the } \\
\text { Poultry Farm, College of Veterinary Medicine, } \\
\text { Baghdad University. The experiment was lasted } \\
\text { for } 42 \text { days started from } 15 / 12 / 2011 \text { up to } \\
25 / 1 / 2012 \text {. Three hundred day-old Hubbard } \\
\text { chicks were divided randomly into } 10 \text { treatment } \\
\text { groups of } 30 \text { birds; each treatment group was }\end{array}$ \\
\hline
\end{tabular}


per replicate. The groups were divided as follow: The $1^{\text {st }}$ group was fed the basal diet as control group. The $2^{\text {nd }}, 3^{\text {rd }}$ and $4^{\text {th }}$ groups were fed the basal diet+0.3, 0.4 and $0.5 \%$ basil powder for the first 3 weeks only respectively. Whereas the $5^{\text {th }}, 6^{\text {th }}$ and $7^{\text {th }}$ groups were fed the same basal diet $+0.3,0.4$ and $0.5 \%$ basil powder for the second 3 weeks respectively. While the $8^{\text {th }}, 9^{\text {th }}$ and $10^{\text {th }}$ were fed the same basal diet with $0.3,0.4$ and $0.5 \%$ basil powder along the whole 42 days.

Live body weight at the end of $3^{\text {rd }}$ and $6^{\text {th }}$ weekswere taken. Body weight gain was calculated as:-

Weight Gain = body weight at the end of the period - body weight at the beginning of the previous period.

Feed intake was at the end of $3^{\text {rd }}$ and $6^{\text {th }}$ weeks, while feed conversion for each treatment along the experiment was measured by the following equation mentioned by (8). Average feed intake $(\mathrm{g})$

Feed conversion $=$ Average body weight gain ( $\mathrm{g}$ )

Statistical analysis was applied by using complete randomized design using statistical analysis system (SAS, 2001).

\section{Results and Discussion}

Live body weight due to effect of sweet basil as a feed additive is presented in table (1). During the first period (1-3weeks old) showed significant $(\mathrm{P}<0.05)$ increase in live body weight for treatments $\mathrm{T} 3, \mathrm{~T} 4$ and $\mathrm{T} 10$ compared with other treated groups and control, but treatments $\mathrm{T} 2$ showed lower live body weight than other treated groups and control.

This could be due to the amount of the active compounds present in sweet basil powder were not quite enough as compared with feed consumed during this period to show an increase in the validity and absorption capability of the nutrient constituent to get benefit from food (9). While during the second period (4- 6 weeks old) the results of T8, T9 and T10 recorded the highest significant $(\mathrm{P}<0.05)$ increase in live body weight as compared with other treated and control groups. However, during the studied period, it was showed a significant $(\mathrm{P}<0.05)$ increase in live body weight in $\mathrm{T} 8$, $\mathrm{T} 9$ andT10 treated groups compared with the other treated and control groups, while T5 showed the lowest value of live body weight compared with other treated and control groups.

Table, 1: Effect of different levels of sweet basil powder on broiler chicks live body weight gain

(g) during different three periods $(\mathrm{M} \pm \mathrm{S}$.E)

\begin{tabular}{|c|c|c|c|}
\hline \multirow{2}{*}{$\begin{array}{l}\text { Parameter } \\
\text { Treatments }\end{array}$} & \multicolumn{3}{|c|}{ Live body weight gain (g) } \\
\hline & $\begin{array}{l}\text { 1st three } \\
\text { wks }\end{array}$ & $\begin{array}{l}\text { 2nd three } \\
\text { wks }\end{array}$ & $\begin{array}{l}\text { Whole } \\
\text { period }\end{array}$ \\
\hline $\mathbf{T 1}$ & $\begin{array}{l}\text { 1061.25 } \\
\text { 112.20de }\end{array}$ & $\begin{array}{r}1215.21 \pm \\
104.61 d\end{array}$ & $\begin{array}{l}2276.46 \pm \\
116.65 \mathrm{de}\end{array}$ \\
\hline $\mathbf{T} 2$ & $\begin{array}{l}1018.74 \pm \\
81.90 \text { ef }\end{array}$ & $\begin{array}{r}1340.74 \pm \\
111.85 \mathrm{c}\end{array}$ & $\begin{array}{l}2359.47 \pm \\
95.76 \text { c de }\end{array}$ \\
\hline $\mathbf{T 3}$ & $\begin{array}{l}1090.10 \pm \\
93.86 \\
\text { a }\end{array}$ & $\begin{array}{l}1267.92 \pm \\
97.38 \\
\text { d }\end{array}$ & $\begin{array}{l}2358.02 \pm \\
121.59 \\
\text { b c }\end{array}$ \\
\hline T4 & $\begin{array}{l}1067.69 \pm \\
99.23 \\
\text { a b }\end{array}$ & $\begin{array}{l}1340.31 \pm \\
97.72 \\
\text { c }\end{array}$ & $\begin{array}{l}2408.00 \pm \\
116.96 \\
\text { b }\end{array}$ \\
\hline $\mathbf{T 5}$ & $\begin{array}{l}1049.18 \pm \\
102.92 \mathrm{~cd}\end{array}$ & $\begin{array}{l}1253.11 \pm \\
125.41 \\
\text { d }\end{array}$ & $\begin{array}{l}2302.67 \pm \\
98.95 \\
\mathrm{e}\end{array}$ \\
\hline T6 & $\begin{array}{l}\text { 1006.75 } \pm \\
91.42 \\
\text { f }\end{array}$ & $\begin{array}{l}1388.13 \pm \\
\text { 118.65 } \\
\text { b }\end{array}$ & $\begin{array}{l}2394.88 \pm \\
78.07 \\
\text { b c }\end{array}$ \\
\hline T7 & $\begin{array}{l}1041.23 \pm \\
86.47 \\
\text { c d }\end{array}$ & $\begin{array}{l}1347.20 \pm \\
120.35 \\
\text { c }\end{array}$ & $\begin{array}{l}2388.42 \pm \\
93.88 \\
\text { bcd }\end{array}$ \\
\hline T8 & $\begin{array}{l}1053.88 \pm \\
62.61 \\
\text { b c }\end{array}$ & $\begin{array}{l}1479.13 \pm \\
112.98 \\
\text { a }\end{array}$ & $\begin{array}{l}2533.00 \pm \\
70.36 \\
\text { b a }\end{array}$ \\
\hline T9 & $\begin{array}{l}1041.39 \pm \\
45.45 \\
\text { c d }\end{array}$ & $\begin{array}{l}1492.62 \pm \\
98.97 \\
\text { a }\end{array}$ & $\begin{array}{l}2534.01 \pm \\
42.52 \\
\text { a }\end{array}$ \\
\hline T10 & $\begin{array}{l}1067.25 \pm \\
31.03 \\
\text { a b }\end{array}$ & $\begin{array}{l}1475.13 \pm \\
99.84 \\
\text { a }\end{array}$ & $\begin{array}{l}2542.38 \pm \\
55.88 \\
\text { a }\end{array}$ \\
\hline
\end{tabular}

Different letters in columns show significant differences at level $(\mathbf{P}<0.05)$.

This significant increase through the $2^{\text {nd }}$ period and the experimental period may be attributed to the fact that basil oils offering the greatest benefits often contain high levels of methyl chavicol, eugenol, linalool, camphor, and methyl cinnamate (10). The lowest gain in the second period of the $5^{\text {th }}$ treatment group could be due to low level of sweet basil powder being fed. Many workers indicated that effect of cinnamate and its derivative compounds has an effect in digestion and feed metabolism, since these compounds have an active role in enhancing the intestine motility and the total secretion of bile through its stimulating role for enzymatic digestive canals secretions and also for the intestine and pancreatic secretion (11). Also it has been shown that the more important active compounds of basil powder is the 
eugenol, it is a phenolic compound that had an antimicrobial property (12). However the synergistic action of both (cinnamate and eugenol) had led to improve the digestive canal status and attenuate the number of microbes in the intestine caused an increase in the available energy for growth, thus these microbes consumes a large amount of digestive nutrients and energy in the intestine needed for maintaining their live which reduces the microbial masses and increases the energyrequirments and cause an improvement in the total body weight (13).

Present results are in agreement with (14) in the importance effect of active substances in the medicinal and aromatic plants (cinnamate and eugenol) as an active substances and digestive stimulators, also its effect as antimicrobials, especially the intestinal microbes that located in the digestives.

Daily Body weight gain was found (Table, 2) there is a significant $(\mathrm{P}<0.05)$ differences between treated groups and the control in the daily body weight gain throughout the first period (0-3wks), second period (4-6wks) and the whole period of the experiment. In the first period (0-3wks), the daily body weight gain of treatments T3, 4 and 10 was significantly $(\mathrm{P}<0.05)$ the highest values compared with other treatments and the control groups. However treatment T8, 9 and 10 in the second three weeks and the whole period recorded the highest gain (70.43, 71.07, 70.24 and 60.30, $60.33,60.53 \mathrm{~g} /$ day) respectively compared with other treated and the control groups (Table, 2).

These results are in agreement with many published research work $(2,15,16$ and 17$)$.

The main constituents of sweet basil include chavicol methyl ether or estragole, linalool and eugenol, and that carried out by Ravid et al., (18) whom suggested that linalool is the most active agent responsible for antibacterial activity, which caused an increase in broilers body weight gain, and linalool considered as the more active antimicrobial among most of sweet basil components and caused sterilization of the gastrointestinal tract, as a result of improving feed utilization and causing an increasing in daily body weight gains. However, other workers found that these improvements may be attributed the effect of chemical constituents (active compounds) of sweet basil powder, which had antimicrobial, antifungal, antioxidant and anti-inflammatory effects $(19,20$ and 21).

Table, 2: Effect of different levels of sweet basil powder on daily body weight gain (g) during different three periods $(M \pm$ S.E)

\begin{tabular}{|c|c|c|c|}
\hline \multirow{2}{*}{$\begin{array}{l}\text { Parameter } \\
\text { Treatments }\end{array}$} & \multicolumn{3}{|c|}{ Daily body weight gain (g) } \\
\hline & $\begin{array}{c}\text { 1st three } \\
\text { wks }\end{array}$ & $\begin{array}{l}\text { 2nd three } \\
\text { wks }\end{array}$ & $\begin{array}{l}\text { Whole } \\
\text { period }\end{array}$ \\
\hline T1 & $\begin{array}{c}50.53 \pm \\
4.58 \mathrm{~d} \text { e }\end{array}$ & $\begin{array}{l}57.86 \pm \\
4.69 d\end{array}$ & $\begin{array}{l}54.20 \pm \\
4.15 \text { de }\end{array}$ \\
\hline $\mathbf{T} 2$ & $\begin{array}{l}48.51 \pm \\
4.09 \text { e f }\end{array}$ & $\begin{array}{l}63.84 \pm \\
3.18 \text { c }\end{array}$ & $\begin{array}{c}56.17 \pm \\
6.13 \text { c de }\end{array}$ \\
\hline T3 & $\begin{array}{c}51.90 \pm \\
5.18 \text { a }\end{array}$ & $\begin{array}{l}60.37 \pm \\
3.35 \mathrm{~d}\end{array}$ & $\begin{array}{c}56.14 \pm \\
5.01 \text { b c }\end{array}$ \\
\hline T4 & $\begin{array}{c}50.84 \pm \\
3.43 \text { a b }\end{array}$ & $\begin{array}{l}63.82 \pm \\
2.36 \text { c }\end{array}$ & $\begin{array}{c}57.33 \pm \\
6.40 \mathrm{~b}\end{array}$ \\
\hline T5 & $\begin{array}{c}49.96 \pm \\
7.61 \mathrm{~cd}\end{array}$ & $\begin{array}{l}59.67 \pm \\
4.21 d\end{array}$ & $\begin{array}{l}55.06 \pm \\
6.68 \text { e }\end{array}$ \\
\hline T6 & $\begin{array}{c}47.94 \pm \\
3.44 \mathrm{f}\end{array}$ & $\begin{array}{c}66.10 \pm \\
2.88 \quad b\end{array}$ & $\begin{array}{c}57.02 \pm \\
5.66 \text { b c }\end{array}$ \\
\hline T7 & $\begin{array}{c}49.58 \pm \\
7.30 \mathrm{c} \mathrm{d}\end{array}$ & $\begin{array}{l}64.15 \pm \\
5.96 \text { c }\end{array}$ & $\begin{array}{c}56.86 \pm \\
4.33 \text { bcd }\end{array}$ \\
\hline T8 & $\begin{array}{c}50.18 \pm \\
4.12 \text { b c }\end{array}$ & $\begin{array}{c}70.43 \pm \\
5.61 \quad \text { a }\end{array}$ & $\begin{array}{c}60.30 \pm \\
5.24 \text { a }\end{array}$ \\
\hline T9 & $\begin{array}{l}49.59 \pm \\
6.25 \mathrm{~cd}\end{array}$ & $\begin{array}{l}\text { 71.07士 } \\
8.37 \text { a }\end{array}$ & $\begin{array}{c}60.33 \pm \\
5.60 \mathrm{a}\end{array}$ \\
\hline T10 & $\begin{array}{c}50.82 \pm \\
5.17 \text { a b }\end{array}$ & $\begin{array}{c}70.24 \pm \\
9.08 \text { a }\end{array}$ & $\begin{array}{c}60.53 \pm \\
6.04 \mathrm{a}\end{array}$ \\
\hline
\end{tabular}

Different letters in columns show significant differences at level $(\mathbf{P}<0.05)$.

In addition, the supplementation of poultry diets with aromic plants have a stimulating effects on digestive system of the animals through the increasing the production of digestive enzymes and by improving the utilization of digestive products through enhanced liver function (22).

The results of this study agreed with (23) who showed that body weight gains of chicks were improved by an increasing herbal mixture supplementation up to $1 \%$ in broiler diets. Also, Abaza (24) found that broiler diets' containing $0.25 \%$ of chamomile improved live body weight and body weight gain.

Feed intake was affected by addition of a sweet basil powder in the diet table (3). 
Table, 3: Effect of different levels of sweet basil powder on daily feed consumption ( $g$ / bird) during different three periods $(M \pm S$.E $)$

\begin{tabular}{|c|c|c|c|}
\hline \multirow{2}{*}{$\begin{array}{l}\text { Parameter } \\
\text { Treatments }\end{array}$} & \multicolumn{3}{|c|}{ Feed intake per day (g) } \\
\hline & $\begin{array}{c}\text { 1st three } \\
\text { wks }\end{array}$ & $\begin{array}{c}\text { 2nd } \\
\text { three } \\
\text { wks }\end{array}$ & $\begin{array}{l}\text { Whole } \\
\text { period }\end{array}$ \\
\hline T1 & $\begin{array}{l}76.99 \pm \\
7.29 \text { a }\end{array}$ & $\begin{array}{c}146.54 \pm \\
5.23 \text { a }\end{array}$ & $\begin{array}{c}111.77 \pm \\
9.59 \mathrm{a}\end{array}$ \\
\hline $\mathbf{T} 2$ & $\begin{array}{c}71.84 \pm \\
3.80 \text { a b }\end{array}$ & $\begin{array}{l}143.83 \pm \\
5.15 \text { a b }\end{array}$ & $\begin{array}{l}107.84 \pm \\
5.47 \text { b c }\end{array}$ \\
\hline T3 & $\begin{array}{l}74.37 \pm \\
8.54 \text { a }\end{array}$ & $\begin{array}{l}142.24 \pm \\
7.95 \text { a b }\end{array}$ & $\begin{array}{c}108.30 \pm \\
9.54 \mathrm{~b}\end{array}$ \\
\hline T4 & $\begin{array}{c}71.77 \pm \\
5.13 \text { a b }\end{array}$ & $\begin{array}{l}136.92 \pm \\
7.55 \mathrm{bcd}\end{array}$ & $\begin{array}{l}104.34 \pm \\
5.20 \mathrm{~cd}\end{array}$ \\
\hline T5 & $\begin{array}{c}69.57 \pm \\
2.92 \text { b c }\end{array}$ & $\begin{array}{l}138.07 \pm \\
9.11 \text { b c }\end{array}$ & $\begin{array}{l}104.13 \pm \\
11.37 \text { c d }\end{array}$ \\
\hline T6 & $\begin{array}{c}72.68 \pm \\
7.07 \text { a b }\end{array}$ & $\begin{array}{c}142.07 \pm \\
8.00 \text { b }\end{array}$ & $\begin{array}{l}107.37 \pm \\
5.50 \text { b c }\end{array}$ \\
\hline T7 & $\begin{array}{c}67.19 \pm \\
7.24 \mathrm{~cd}\end{array}$ & $\begin{array}{c}135.74 \pm \\
7.27 b \\
\text { cd }\end{array}$ & $\begin{array}{l}101.46 \pm \\
5.26 \mathrm{~d} \text { e }\end{array}$ \\
\hline T8 & $\begin{array}{c}65.02 \pm \\
9.85 \mathrm{~d} \mathrm{e}\end{array}$ & $\begin{array}{l}132.53 \pm \\
7.01 \mathrm{~cd}\end{array}$ & $\begin{array}{c}98.78 \pm \\
7.41 \text { e f }\end{array}$ \\
\hline T9 & $\begin{array}{c}61.77 \pm \\
12.49 \text { e }\end{array}$ & $\begin{array}{l}130.71 \pm \\
9.14 \mathrm{~cd}\end{array}$ & $\begin{array}{l}96.24 \pm \\
11.81 \text { f }\end{array}$ \\
\hline T10 & $\begin{array}{l}67.22 \pm \\
4.13 c d\end{array}$ & $\begin{array}{l}130.16 \pm \\
11.29 d\end{array}$ & $\begin{array}{l}98.69 \pm \\
3.78 \text { e f }\end{array}$ \\
\hline
\end{tabular}

Different letters in columns show significant differences at level $(P<0.05)$

The results showed that there was a significant difference $(\mathrm{P}<0.05)$ in feed intake during the first period (1-3 weeks), second period (4-6 weeks) and also whole period. In the first period $\mathrm{T} 8$ and $\mathrm{T} 9$ showed significantly $(\mathrm{P}<0.05)$ lowered feed intake than other groups. A significant $(\mathrm{P}<0.05)$ difference noticed in feed intake for the second three weeks and whole periods among the treated groups, while T8, T9 and T10 groups shows a significantly $(\mathrm{P}<0.05)$ lowered feed intake in whole period as compared with other groups, especially the control group showed the highest level of this trait. Present results agreed with Yurtseven et al., (25) found significant and linear reduction in feed intake due to sage extract (which is below the same family) occurred in weeks 9 to 12 ofage of the partridges.

Rabia, (26) indicated that feeding different types of MAP as feed additive significantly $(\mathrm{p}<0.05)$ affected feed intake $(\mathrm{FI})$ value during the experimental period, indicated that broiler fed basil, parsley and fenugreek seeds had the lower feed intake value during 42 days of age as compared with the control group. While Abd EL-Latif et al., (27) found that the lowest values of feed intake and best feed conversion ratio with the addition of $0.5 \%$ chamomile flower to the Japanese quail feed diets. Mehmet et al., (28) found that feed intake was reduced linearly by increasing doses of black seeds extract during 0 to 12 weeks of age. The results in this study were in contrast with the findings of Erener et al., (29) who found that supplementation of black seeds increased feed intake of broiler chicks. However, the results of this study were in contrast with Cabuk (14) found that feed intake be improved with the addition of MAP and attributed to essential oils and their main components which stimulate the appetizing and digestive process in animals.

The lowest values of feed intake in this study occurred in the groups those treated with sweet basil powder, these may be attributed to the strong smell and sharp taste of the extract since these are properties known to characterize antioxidants in basil plants (30).

Table, 4: Effect of different levels of sweet basil powder on daily feed conversion ratio (g/body wt. /feed intake) during different three periods $(\mathrm{M} \pm \mathrm{S} . \mathrm{E})$

\begin{tabular}{|c|c|c|c|}
\hline \multirow{2}{*}{$\begin{array}{l}\text { Parameter } \\
\text { Treatments }\end{array}$} & \multicolumn{3}{|c|}{$\begin{array}{l}\text { Feed conversion ratio } \\
\text { (Feed intake/ g/body wt.) }\end{array}$} \\
\hline & $\begin{array}{l}\text { 1st three } \\
\text { wks }\end{array}$ & $\begin{array}{l}\text { 2nd three } \\
\text { wks }\end{array}$ & $\begin{array}{l}\text { Whole } \\
\text { period }\end{array}$ \\
\hline T1 & $\begin{array}{l}1.52 \pm 0.04 \\
\text { a }\end{array}$ & $\begin{array}{l}2.54 \pm \\
0.31 \mathrm{a}\end{array}$ & $\begin{array}{l}2.06 \pm \\
0.05 \text { a }\end{array}$ \\
\hline $\mathbf{T 2}$ & $\begin{array}{c}1.48 \pm 0.04 \\
\text { a b }\end{array}$ & $\begin{array}{c}2.25 \pm \\
0.22 \text { b c }\end{array}$ & $\begin{array}{l}1.91 \pm \\
0.02 \mathrm{~b}\end{array}$ \\
\hline $\mathbf{T 3}$ & $\begin{array}{c}1.43 \pm \\
0.02 \text { b c }\end{array}$ & $\begin{array}{l}2.36 \pm \\
0.04 b\end{array}$ & $\begin{array}{l}1.92 \pm \\
0.02 \mathrm{~b}\end{array}$ \\
\hline T4 & $\begin{array}{l}1.41 \pm 0.06 \\
\text { cd }\end{array}$ & $\begin{array}{l}2.14 \pm \\
0.02 \mathrm{c}\end{array}$ & $\begin{array}{c}1.81 \pm \\
0.08 \mathrm{~cd}\end{array}$ \\
\hline T5 & $\begin{array}{c}1.38 \pm \\
0.04 \mathrm{~cd} \mathrm{e}\end{array}$ & $\begin{array}{l}2.34 \pm \\
0.23 \text { b }\end{array}$ & $\begin{array}{c}1.89 \pm \\
0.04 \text { b c }\end{array}$ \\
\hline T6 & $\begin{array}{c}1.51 \pm 0.06 \\
\mathrm{a}\end{array}$ & $\begin{array}{l}2.14 \pm \\
0.24 \mathrm{c}\end{array}$ & $\begin{array}{c}1.88 \pm \\
0.02 \text { b c }\end{array}$ \\
\hline $\mathbf{T} 7$ & $\begin{array}{c}1.35 \pm \\
0.03 \mathrm{~d} \text { e f }\end{array}$ & $\begin{array}{l}2.12 \pm \\
0.23 \text { b }\end{array}$ & $\begin{array}{l}1.78 \pm \\
0.03 d\end{array}$ \\
\hline T8 & $\begin{array}{c}1.29 \pm \\
0.02 \text { f g }\end{array}$ & $\begin{array}{l}1.88 \pm \\
0.21 \mathrm{~d}\end{array}$ & $\begin{array}{l}1.63 \pm \\
0.06 \mathrm{e}\end{array}$ \\
\hline T9 & $\begin{array}{l}1.24 \pm \\
0.05 \mathrm{~g}\end{array}$ & $\begin{array}{l}1.83 \pm \\
0.17 \mathrm{~d}\end{array}$ & $\begin{array}{l}1.59 \pm \\
0.09 \text { e }\end{array}$ \\
\hline T10 & $\begin{array}{c}1.32 \pm \\
0.02 \text { ef }\end{array}$ & $\begin{array}{l}1.85 \pm \\
0.11 \mathrm{~d}\end{array}$ & $\begin{array}{l}1.63 \pm \\
0.08 \text { e }\end{array}$ \\
\hline
\end{tabular}

Different letters in columns show significant differences at level $(\mathbf{P}<\mathbf{0 . 0 5})$ 
Feed conversion ratio is regarded as an the bird to convert the diet into a live body weight. Significant $(\mathrm{P}<0.05)$ differences were observed (table,4) in feed conversion ratio among treated and control groups in the three periods, however, T8,T 9 and T10 in the $2^{\text {nd }}$ period and whole period of the experiment showed a significant $(\mathrm{P}<0.05)$ improvement as compared with other treatments and control groups, they recorded 1.85,1.83,1.88 and $1.63,1.59,1.63$ respectively.

Present results were supported with the findings (31) indicated that there was an improvement in feed conversion with herbal products used as feed additives, and could be

\section{References}

1. Vienna, F. Ch.; Graz, B. R.; Hohenheim, C. R.; Milano, T. D.; Trieste, T. A. and Wien, Z. K. (2005). Assessment of plants / herbs, plant/herb extracts and their naturally or synthetically produced components as "additives" for use in animal production. CFT/EFSA/FEEDAP/1.

2. Craig, W.J. (1999). Health-promoting properties of common herbs. Am. J. Clin. Nutr.,70 (3): 491-499.

3. Herbs Society of America (2004). Basil: An herb Society of America Guide: Medicinal and Ethnobotanical uses. http//www. herbsociety. org/ basil/bmedic. Htm .

4. Tucker, L. (2002). Botanical broiler: Plant extracts to maintain poultry Performance. Feed Int., 23: 26-29.

5. Alcicek, A.; Bozkurt, M. andCabuk, M. (2004). The effect of a mixture of herbal essential oils, an organic acid or a probiotic on broiler performance. S. Afr. J. Anim. Sci., 34: 217-222.

6. Osman, M.; Amber, K.H. and Mahmoud, M.A. (2004). Response of broiler chicks performance to partial dietary inclusion of radish, rocket and parsley cakes. Egypt. Poult. Sci., 24: 429-446.

7. Abdel-Azeem, F. (2006). Effect of using fenugreek and fennel seeds as natural feed additives on performance of broiler chicks. Egypt. J. Nurt. Feeds, 9: 277-297.

8. Al-Zubaydi, SS. (1986). Poultry management. First ed., MSc. Thesis, College of Agriculture. Basrah University. important economic indicator on the ability of attributed to their effect on improving the digestibility of dietary protein in the small intestine. Narahari et al., (32) reported that basil leaves and other herbs be added in laying hens diet improved the egg weight, feed efficiency and health of hens.

In conclusion the highest body weight and the lowest Feed conversion ratio were related to $0.3 \%, 0.4 \%, 0.5 \%$ groups, it could be postulated that to the antioxidant, antifungal and antiseptic activities of O.basilicum which may protects the chicks diet from oxidation and save the value of vitamins and proteins of the diet.

9. Hamodi, S.J. and Al-Mashhadany, H.E. (2008). Effect of addition chamomile flower powder to diet on productive properties and carcass quality properties on physiological and microbial to broiler chicks, J. Agricul. Res., 34 (3) 871-891.

10.Li, X. and Hedge, I.C. (1991). 'Ocimum' in Flora of China, 17:296. Published by Science Press (Beijing) and Missouri Botanical Garden Press. On line at http:/www.efloras. org.

11.Ranasigle, L.; Jaqewardene, B. and Abeyeickrama, K. (2002). Fungicidal activity of essential oils of cinnamomumzeylani aim $\mathrm{L}$ and sqzygiamaromatiam L Merret, L. M. Perry asaist crown rotany anthracnose pathogens isolated from banana left. App. Microbiol., 35: 208-221.

12.Lawless, L. (1995). The illustrated Encyclopedia of Essential Oil ISBN.

13.Didry, N.; Dubreuil, L. and Pinkas, M. (1994). Activity of thymol, carvacrol, cinamaldehyde and eugenol on oral bacteria. Pharm. Acta. Helvetiae, 69:25-28.

14.Cabuk, M.; Alcicek, A.; Bozkurt, M. and Imir, N. (2003). Anti- microbial properties of the essential oils isolated from aromatic plants and using possibility as alternative feed additives. II. National Animal Nutrition Congress, 18-20 September, Konya, Turkey, PP: 184-187.

15.Triantaphyllou, K.; Blekas, G. and Boskou, D. (2001). Anti- oxidant properties of water extracts obtained from herbs of the species 
Lamiaceae. Internat. J. Food Sci. Nut., 52: 313-317.

16.Abdo-Zeinab, Z.M.; Soliman, A.Z. and Barakat, O.S. (2003). Effect of hot pepper and marjoram as feed additives on the growth performance and the microbial population of the gastrointestinal tract of broilers. Egypt Poult. Sci. J., 23 (1): 91-113.

17.Soliman, A. Z..; Ali, M. A. and Abdo-Zeinab, M. A. (2003). Effect of marjoram, bacitracin active yeast as feed additives on the performance and the microbial content of the broiler's intestinal tract. Egypt Poult. Sci. J., 23 (3): 445-467.

18.Ravid, U., Putievsky, E., Katzir, I. and Lewinsohn, E. (1997). Enantiomeric composition of linalool in the essential oils of Ocimumspecies and in commercial basil oils. Flavour Fragr. J., 12: 293-296.

19.Ali, M. A. (1999). Effect of probiotics addition to broiler rations on performance and some blood constituents. Egypt Poult. Sci. J., 19: 161-177.

20.Uma-devi, P. (2001). Radioprotective, anticarcinogenic and antioxidant properties of the Indian holy Basil, Ocimum sanctum (Tulasi). Indian J. Exp. Biol., 39:185-190.

21.Padurar, I., Paduraru, O. and Miron A. (2008). Assessment of antioxidant activity of Basilica herba aqueous extract in vitro studies. Farmacia., 160(4):402-408.

22.Hernandez, F.; Madrid, J.; Garcia, V.; Orengo, J. and Megias, M. D. (2004). Influence of two plant extract on broiler performance, digestibility and digestive organ size. Poult. Sci., 83: 169-174.

23. Abdel-Malak, N. Y.; Abdel-Malak, M. S.; ElGendi, G. M. and Naguib, E. F. (1995). Effect of feeding different levels of herbal feed additive on broiler performance in relation to some metabolic functions. Egypt. Poult. Sci., 15:111-139.

24.Abaza, I. M. (2007). Effect of using fenugreek, chamomile and radish as feed additives on productive performance and digestibility coefficients of laying hens. Poult. Sci., 27: 199-218.
25. Yurtseven, S.; Çetin, M.; Şengul, T. and Sogut, B. (2008). Effect of sage extract (Salvia officinalis) on growth performance, blood parameters, oxidative stress and DNA damage in partridges. South African J. Ani. Sci., 38 (2):92-98.

26.Rabia J. A. (2010). Effect of using fengugreek, parsley and sweet basil seeds as feed additive on the performance of broiler chickens. Intern. J. Poult. Sci., 9 (3): 278282.

27.Abd El- Latif, S. A.; El- Yamany, A. T. and Eman, A.F.(2004). Evaluation of using different levels and sources of medicinal herbs in growing Japanesse quail diets. Egypt J. Nut. Feeds, 7(1): 69-81.

28. Mehmet, C.; Sabri, Y.; Turgay, S. and Bunyamin, S. (2008). Effect of black seed extract (Nigella sativa) on growth performance, blood parameters, oxidative stress and DNA damage of Partridges. J. Appl. Ani. Res., 34(2): 122-128.

29.Erener, G.; Altop, N.; Ocak, H.; Aksoy, S. and Ozturk, E. (2010). Influence of black cumin seed (Nigella sativa L.) and seed extract on broilers performance and total coliform bacteria count, Asian J. Anim. Vet. Adv., 5: 128-135.

30.Telci, I.; Bayram,E.; Yilmaz,G. and Avci, B. (2006). Variability in essential oil composition of Turkish basils (Ocimum basilicum L.). Bioch. Systematic Ecol., 34: 489-497.

31.El-Gendi, G. M.; Ismail, F. A. and ElAggoury, S. M. (1994). Effect of coccinel and lomoton dietary supplementation as herbal growth promoters on productive performance of broiler. Ann. Agric. Sci. Moshtohor., 32: 1511-1528.

32.Narahari, D., Kirubakaran, A., Ahmed, M. and Michelraj P. (2004) .Improved designer egg production using herbal enriched functional feeds. In: Proceedings of the XXII World Poultry Congress, 8-13 June, Istanbul, Turkey. 


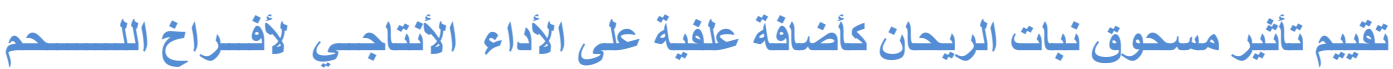

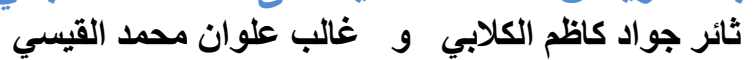

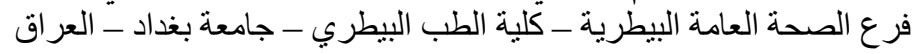

\section{الخُلاصة}

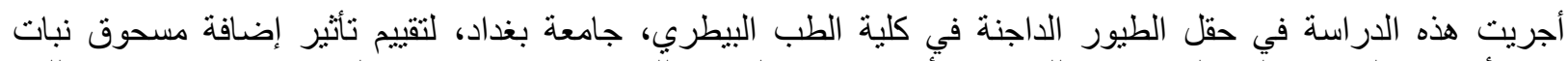

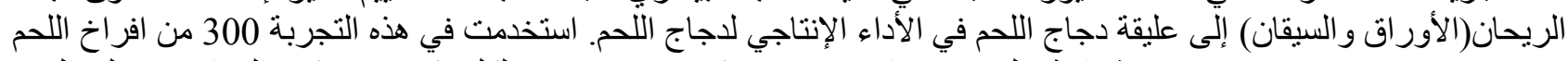

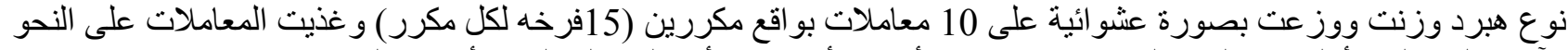

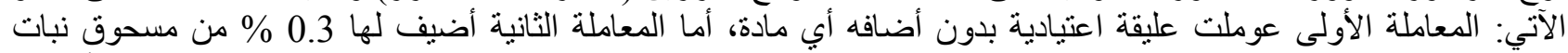

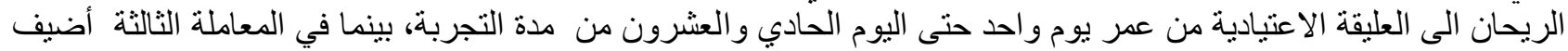

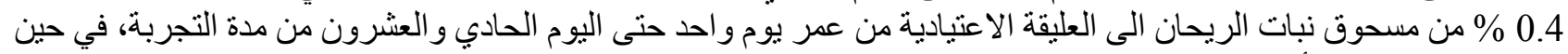

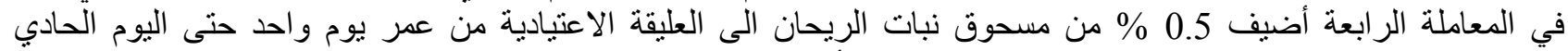

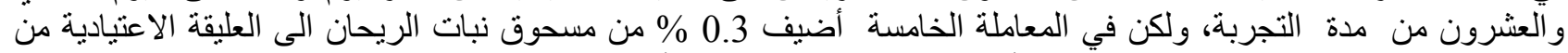

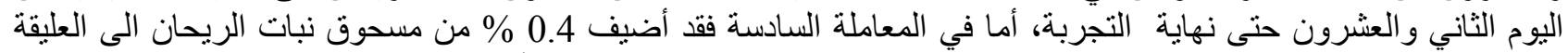

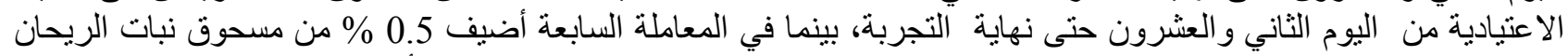

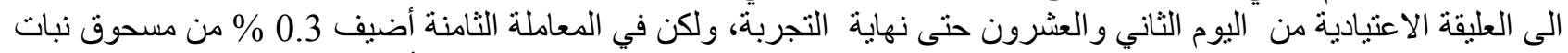

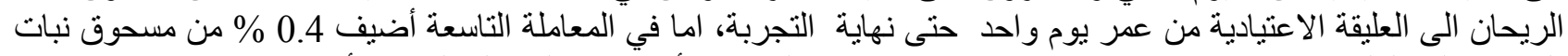

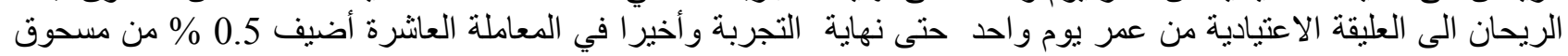

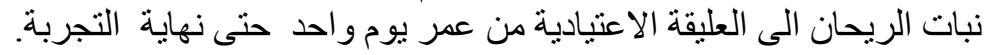

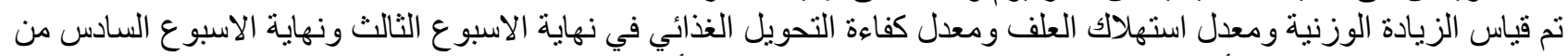

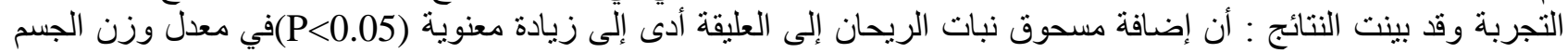

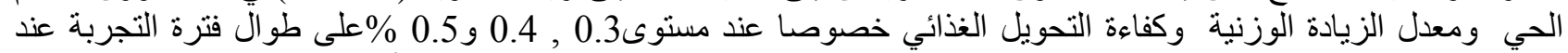

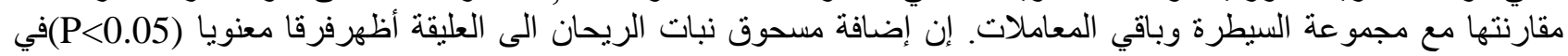

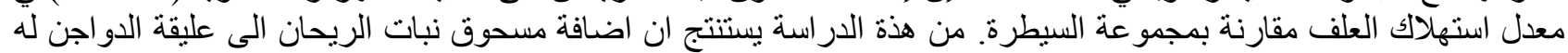
تاثيرفي الاداء الانتاجي لدجاج اللعارئ

الكلمات المفتاحية: مسحوق نبات الريحان، اضافات علفية، افراخ اللحم، الاداء الانتاجي. 